\title{
Production systems in primary education
}

\author{
Igor Vitrih \\ Osnovna šola Neznanih talcev Dravograd \\ Trg 4. julija 64, 2370 Dravograd \\ igor.vitrih@os-dravograd.si
}

\begin{abstract}
In the article I try to present the contents of production systems (general theoretical starting points and concrete examples from practice) in connection with the contents of the Slovenian primary school curriculum in the subject Technic and Technology and its elective subjects (Processing of materials - wood). I sought these connections mainly from the curriculum in the primary school curriculum, which relates to learning about wood, wood semi-finished products, wood machining and tried to connect them with the previously mentioned contents of production systems and thus give students a broader insight into such content.
\end{abstract}

Keywords: production systems, glues, production of glues, company Ledinek, primary school, project work, preparations.

\section{Introduction}

Primary education should be primarily education for life and understanding of certain processes in society. The given contents of education should be as practical and useful as possible in everyday life. Precisely the subject Technic and Technology is a subject in which such content is given. The mentioned subject is the acquisition of knowledge and understanding of learning contents, especially on concrete cases. Since we get to know the problem, which usually refers specifically to certain real cases and this problem must be understood holistically, this type of content and appropriate learning methods related to this content must be introduced into the teaching of Engineering and Technology and its electives.

A good example from practice, which refers to the contents of the TAT course and its elective courses, is the presentation of the production process in the case of the company Ledinek. I find this company very attractive for placement in the learning content of TAT and its elective subjects precisely because of the interesting content, the intertwining of individual technical directions within the technological process, advanced technology and the company's penetration into the world market. A concrete example of the transfer of these contents into the educational process is found in learning about the types of glued wood, methods of making glued wood and learning about the entire production process, from idea to realization, the production lines themselves for making glued wood.

\section{About production systems}

In a world of growing economic and economic crises, where the policy and management of companies or people in these positions ask how to improve only productivity, trade, how to improve the division of labor in the market, the essence of the answer is the organization of labor. The organization of work is a broad problem and relates specifically to production, as well as to all the factors involved outside it. Its 
solutions are visible in the rationalization of labor costs, business economics, etc. (Polajner, 2007).

Since this is an area related to the labor market and continuous technological improvements, the contents of the organization itself are changing or adapt to the needs of this market. It was for this reason that in 1924 an organization of an educational nature, the so-called REFA Committee, began to emerge. It deals with various methods of economic management of production, especially the study of work. Today, all these methods are given a common name: production organization (Polajner, 2007).

In the following scheme (Figure 1), we can understand and find the reasons for emphasizing the study of labour as an important part of the organization of production. These are common characteristics (common goals, construction of findings from a labour study, etc.), but the organization of production covers a wider area (Polajner, 2007).

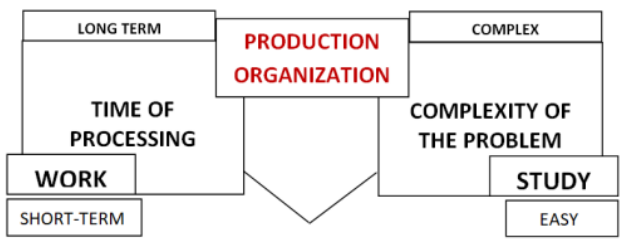

Figure 1: The connection between the organization of production and the study of labor

The organization of production is constantly changing, as it is necessary to take into account the constant technological progress. According to market requirements and competition, the organization of production must be adjusted accordingly and priorities must be taken into account (product quality and the ability to achieve low prices, trust, flexibility, etc.). The essential components that also need to be taken into account when organizing production are: determining the workplace, method and mode of work; determination of production time; economic analysis of the validity of the technological process and study of work (Polajner, 2007).

The study of labour is an important part of the organization of production. It is a science of work and covers areas from ergonomics, work pedagogy, technology, statistics, business economics, etc. Its content and objectives can be summarized in the following definition: "The study of work is the scientific study of working methods and procedures and the design of work on the principles of economy, taking into account the principles of safety, ergonomics, psychology, physiology, standard rules of rational work and systems theory." (Polajner, 2007, p. 7).
The study of work is of key importance in the organization of production because the organization itself or other key elements of the organization of production are adapted to the contents and goals achieved within the study of work. Such an example (changes in certain production lines through the historical development of production), depending on the study of work, can also be felt at the company Ledinek, which I will also present below.

Production itself experienced its purpose and real rise with the beginning of the Industrial Revolution (steam engine, James Watt, I. 1764). This form differed significantly from previous craft and other works, precisely in the technical division of works, organization, specificity of roles, and so on. In essence, it is a matter of replacing rather timeconsuming manual labour with a faster replacement of mass production with a cheaper service (Polajner, 2007).

The organization of production is a technical area. $\mathrm{He}$ is engaged in research, design, production improvement, preparation, coordination, and monitoring of technologies and production process. In this way, we get the product at optimal costs in the planned time and in the desired quantity and quality. The organization of production involves additional contents of economic and sociological fields, and therefore interdisciplinary dimensions. The organization of production itself is divided by tasks into several departments in the work organization in terms of rationalization tasks and also requires a broad knowledge of the people who work in these areas (Polajner, 2007).

In general, the organization of production includes:

- study of work;

- production design;

- work with materials;

- maintenance;

- quality control;

- production planning and monitoring;

- design of technological and production process (Polajner, 2007, p. 4).

The organization of production includes three basic elements of operation: organization, planning and control.

Planners in the planning phase (Figure 2) design important goals and the path to the realization of goals, of course within the capabilities of a particular company, its strategies, etc. Later, this concept is transferred to the very structure of production within the organization, the division of the system into units, the allocation of roles, responsibilities to individual units. It is necessary to definitely control everything, look for new solutions, improvements, 
etc. through knowledge. This is also made possible by pre-prepared models, a kind of solution to problems that have already arisen in previous cases. In the end, the relationship, effort and behaviour play an important role in terms of responding to the results of work on the one hand, especially managers, as well as on the other hand production workers (Polajner, 2007).

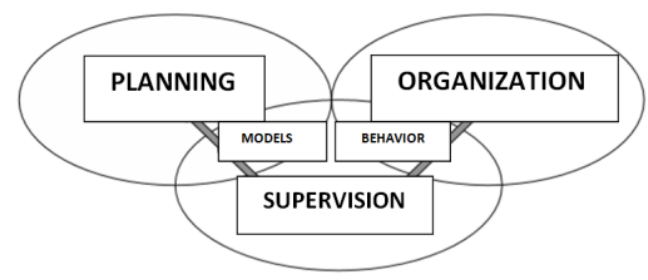

Figure 2: Production organization

As the field of engines has evolved in the sense that steam power has replaced gasoline and electric engines over time, the field of production has gained weight after a century of effort on its scientific weight and study (beginner Frederick Winslow Taylor) and of course on its own development. In practice, this was best demonstrated by the use of prefabricated lines (Model $\mathrm{T}$ ) by automobile manufacturer Henry Ford in the 20th century (Figure $5)$. The then production division of labor reaches its peak in terms of a systemic approach to work, which raises this philosophy of production to an even higher level of quality (Polajner, 2007).

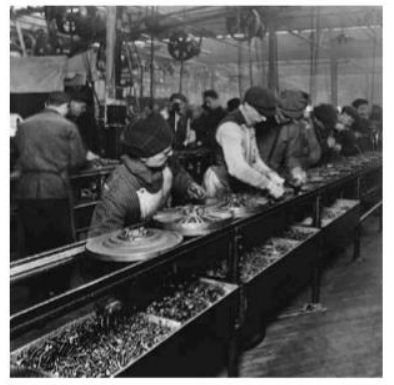

Figure 3: Ford line

Production is present in all economically developed countries of the world and offers various services (final products, raw materials, semi-finished products, energy products, information products (plans, data). Production is any activity that creates value. Production can, in addition to engaging in economic activities, also engage in non-economic ones. But the product is always an important result (Polajner, 2007).

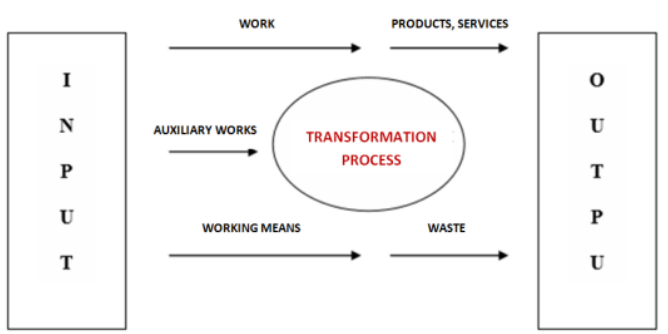

Figure 4: Production process scheme

The production process itself is set through the scheme shown above (Figure 4) and shows a combination of work, object of work and working means as inputs for creating products (outputs). It is this transformation process that is the essence of the production work process (Polajner, 2007).

Production systems refer to production only, production processes and consist of:

- entries into the system;

- production goods;

- exits from the system;

- workers;

- working capital;

- environmental impacts on the system itself (Polajner, 2007).

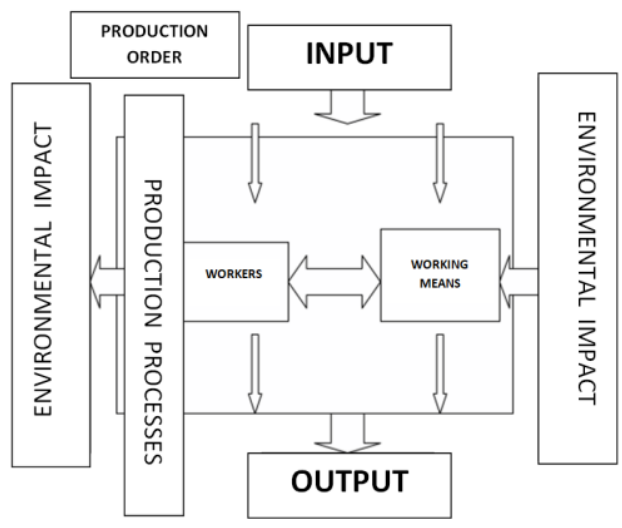

Figure 5: Production system scheme

With the production task or with the work task (Figure 5) we determine the main activity or what we will produce. In addition to the main ones, there are also ancillary activities (storage, transport, various research, education, etc.). This production task is later divided into several smaller work tasks, according to the type of work; the place where this work will be performed; and the necessary knowledge and tools needed for this work (Polajner, 2007).

A person with his information, knowledge and available energy and materials brings entry into the system itself, where through working means (tools, equipment) workers, as the most important member 
of the system, get it as an exit from the system. The output is a product, of course, in addition to waste, which can leave negative consequences in the environment, for which the system pays more and more attention to it and tries to reduce these consequences. We also know other influences of the environment (social, organizational or craft or industrial mode of production) and general social influence (Polajner, 2007).

The production systems themselves are different and are divided into systems that include production to order or in stock. They are also divided into individual (craft) production, where it is the entire production cycle of the final product, production of the product (model) and then documentation, and industrial, where the process begins first with documentation. Industrial production, which does not carry out the entire cycle until the final product, but manufactures individual components in larger and smaller batches, which can of course be replaced in the final product. Therefore, this type of industrial production is called serial production and is divided according to the amount of parts produced into individual (1 to 10 products), small-batch, mediumbatch and large-batch production. On the other hand, we have another type of industrial production, namely mass production, which produces products for multipurpose use, with standardization and typification (Polajner, 2007).

Figure 6 (below) shows an example of direct production in dependence and connection with other parts of the production system. Production gets the task from the preparation of production and gives feedback back to the preparation of production and also to the construction. The essence of production is to turn a raw material into a product through the production process (Polajner, 2007).

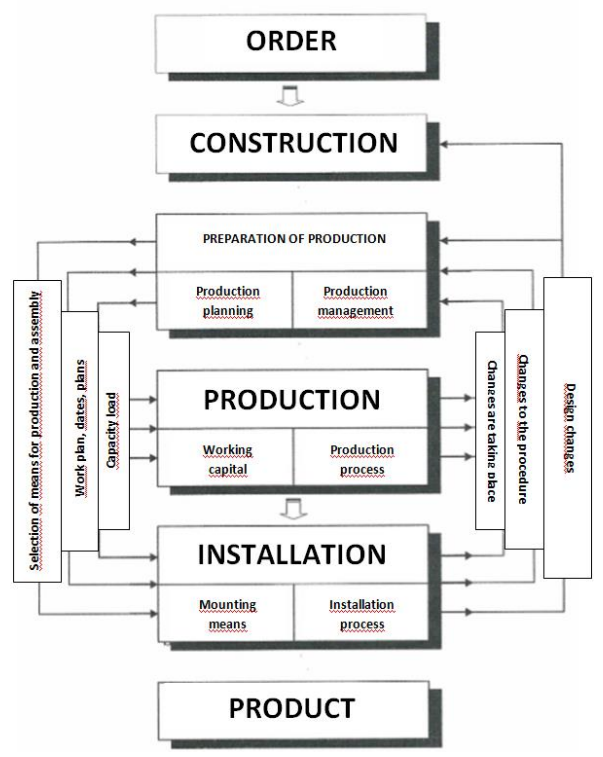

Figure 6: Demonstration of the direct production scheme with other components of production systems e.g. in project work

\section{Ledinek production systems}

The Ledinek Company is a family company that has been dealing with wood processing for 100 years. Over time, with the change of services, it has become one of the most successful and developed companies in the world in the field of design and manufacture of woodworking machines and devices. Their progress and success are undoubtedly the result of close cooperation between research institutes and the company, the transfer of research results into the production process itself and the appropriate knowledge of the staff they have. The company's results are visible in as many as 45 countries around the world (www.ledinek.com).

Today, Ledinek is one of the most important manufacturers of woodworking machinery and equipment in the world. The company's offer program itself includes individual machines, as well as components of production lines by upgrading its own development ideas and patents. The company's advantages are also: adapting the wishes of customers, the highest quality installation of machine parts or production lines from renowned manufacturers, scientific research and continuous training of staff. The company cooperates with many foreign business partners, such as. Systemholz Gaishorn Austria, Minda Germany, Ogden USA, Springer Austria, Wiesner - Hager Altheim Austria, Univerzität Stuttgart and others. In the last five years, the company has applied for innovations, patents and scientific publications, mainly related to calibration with Rotoles machines (awarded in Atlanta), Kontizink flow press lines and butt joint systems, wood gluing systems, etc. All the efforts invested by the company in development and progress have paid off over the years, as the company has become one of the world's leaders in the field of equipment for the production of glued wood (summarized from the internal material of the company Ledinek).

The Ledinek company offers complete production concepts (solutions, ideas) through some organized work from the input (logs), sawing (rough processing) and all the way to the final product (with the help of the company's production products), which are only one segment in the production system. www.ledinek.com). In the following (Figure 7) I show the whole concept, which in addition to the previously mentioned products (production machines, lines) is offered in the company as a complete solution. 


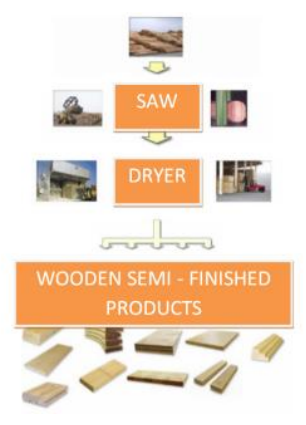

Figure 7: Concepts of production processes

This is followed by some products from the company Ledinek, which are offered, as part of the solution, to production plants in the field of wood processing.
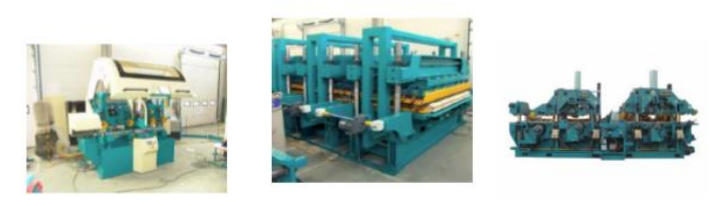

Figure 8: Some of the machines of the company Ledinek

\section{Introduction of content in primary education in Slovenia}

The presented contents can be introduced in the primary school program in the subject TAT, as well as in elective subjects and elective contents. The subject Technic and Technology (content areas wood and technical drawing) and the optional subject Processing of materials (wood) are subjects where frequent introduction of content from the field of production systems is possible. This connection and the introduction of such contents are reflected mainly in the use of various learning forms, of which the project approach (project task) is the most complex, and therefore the most important for a comprehensive presentation of the set issues. Students thus gain insight into the very design, preparation, organization and realization of the set ideas. If I refer to the presentation of Ledinek in previous chapters and their organizational structure as a production system and the connection of direct production with other parts of production systems, we see that the key elements of production systems are: design, construction, preparation of technical documentation, production organization, the course of production work), assembly and final control of the product, if we do not expose before (market research, etc.) and after-sales activities (servicing and maintenance).

Each project that we carry out within the learning unit must be prepared on the basis of special didactic reflection, which contains the following elements (Aberšek, 2012):

1. Setting the objectives of the project work;

2. Examination of the complexity of learning objectives (students' prior knowledge should not be underestimated or overestimated);

3. Planning of learning forms - changing frontal lessons, individual work, and possible work in pairs or in a group;

4. Preparation of appropriate working conditions (eresources, information - classic resources, knowledge of experts, tools, jobs, machines);

5. Cross-curricular links, including outside the school curriculum;

6. Determining the time frame of the project.

We can use various forms of learning to present the problem, from design or production. If we want to tackle the problem comprehensively, we can use the project way of working. In this way, it is necessary to emphasize that there are many definitions of what a project and project work or the project task is and that these definitions are different from each other, but they still have something in common. Based on the common characteristics, the project could be defined as a set of certain activities that are carried out in a certain time with limited resources, set goals and purposes and according to plan (Aberšek, 2012).

Project work is mainly characterized by:

- is limited in time, has a beginning and an end; most often it is a one-time process; has clear goals that we want to achieve;

- follows the plan. It is this planning process that makes the essential difference between problem and project work;

- contains the necessary resources.

Let's look at a comparison of the differences between the classic organization of production (can also be lessons) and project management (Table 1).

\begin{tabular}{|l|l|}
\hline Classical organization & Project management \\
\hline - Often unclear goals & - Specific goals \\
- Constant requirements & - Limited requirements \\
- Time norm & - Difficult time calculation \\
- Repetitive tasks & - Unique, new tasks \\
- Known costs & - Estimated costs \\
- Functional efficiency & - The result \\
- Area cooperation & - Teamwork \\
\hline
\end{tabular}

Table 1: Comparison of classical organization and project management 
How can we transfer this to school? Project work in school should illustrate the project in a real environment, project organization and project management. It is necessary to pursue global project goals and simplify them to the extent that they retain the spirit of the project and project work in a real environment (Aberšek, 2012).

In the subject Technic and Technology and its elective subjects, we are not only talking about acquiring psychomotor skills, ie skills, habits, but also about the creative approach to work (new work procedures, new learning and working tools, tools, etc.). The use of the project task in the process of primary education itself also tends to this (Papotnik, 1984).

When we talk about the articulation of lessons, we are talking about structuring (breaking down, shaping) the learning process in a certain unit of time. On articulation, all modern didactics agree that it is not the stenciling of the learning process, but creative design (Papotnik, 1998). Articulation is equally important in shaping the learning process through a project assignment.

The project task is one of the strategies (types) of educational work. It is a form of production work, organized from the idea, prototyping, technical and technological documentation, serial production, work analysis and evaluation and product - project. This strategy makes it possible to get to know the productive interpersonal relationships in practice. Students learn about technical professions, serial analysis of learning material and production and other areas (socio-economic) in the evaluation of product value (Papotnik, 1984). This strategy became important already in the reform times of education, as it introduced students to production processes of work for later jobs, which could also be performed later (Papotnik, 1998).

"The project task consists of educational units, tasks, operational goals at all levels of Bloom's taxonomy for the educational (cognitive), educational (conative) and psychomotor areas of goal planning." (Papotnik, 1998, p. 43).

It can consist of seven learning units, namely (according to Papotnik):

1. Product planning and development;

2. Prototyping;

3. Constructions (preparation of technical and technological documentation);

4. Preparation of serial production;

5. Excursions;

6. Execution of production work on the conveyor belt;

7. Completion of production work. (Papotnik, 1998, p. 43).

\section{Project work on the example of the company Ledinek}

As soon as we connect through a project task to a certain company (as an example in practice), which produces a product in an organized structure, in addition to the organization itself, which is related to project work in the classroom, we are also interested in the product itself. This also gives us a holistic picture, an understanding of how a certain product is made, what it is used for, and so on.

In understanding the production process, e.g. Ledinek company and the final products of this company, students learn two things: they approach the way of organizing production (not only through the project task, but also in the concrete case of the company; and the product itself, which in the case of Ledinek machine or production line which manufactures wood materials for certain purposes of use (construction of houses, furniture, etc)). Here I can relate to the material from the curriculum in the subject Engineering and Technology (content area wood) and to the elective course processing materials (wood) dealing with wood materials and machines for processing such materials.

In the following, I would like to highlight the key points of the learning content of these two subjects in connection with the above-mentioned Ledinek products and their applicability.

If we move on to the search for such a correlation and limit ourselves for the time being to the field of learning and processing wood, we notice that does not change much, also taking into account the literature in primary education. In essence, the optional subject Processing of materials (wood), which is taught in the 7th grade of the primary school curriculum, is a kind of upgrade of knowledge about wood in terms of a larger share of practical work with wood material.

If I focus on the theoretical knowledge of wood (mostly in the 6th grade in the subject Technic and Technology), that is, on wood materials and wood semi-finished products, it would be good that when this type of learning issues are addressed in school, a variety of prescribed to certain contents that are related to concrete examples from practice and to later possible project work (in the subject Technic and Technology or in the optional subject Processing of materials-wood).

In most of the prescribed literature, which is intended for the subject Technic and Technology and its elective subjects in primary education, getting to know wood is also about getting to know the aforementioned wood semi-finished products (plywood, hardboard, panel boards, etc.). 
In the following, I present an excerpt from the teaching material, which presents these semifinished products-glued (I limited myself to the more current laminated wood for me).

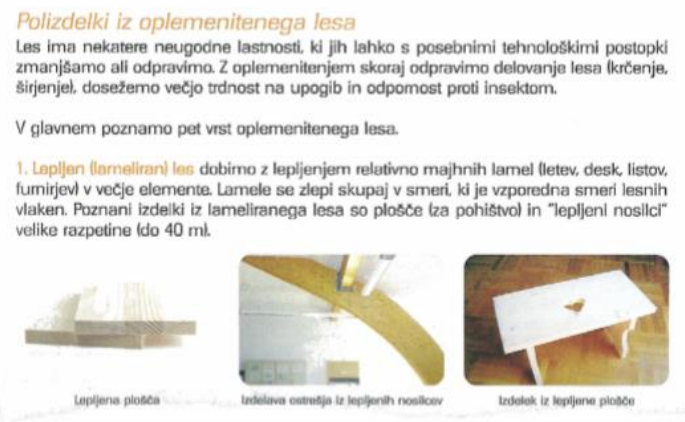

Figure 11: Example of presentation of glued (laminated) wood

Figure 11 shows an excerpt of the presentation of laminated wood (source: Fošnarič, S., Pucer, Z., Slukan, D., Virtič, J.) (2004) Technique and technology 6. Textbook for the 6 th grade of a nine-year primary school. Izotech publishing house.). During the presentation, it would be sensible to present the types of glued (laminated) wood (BSH, DUO-TRIO beams, X-Lam), which I will not discuss in particular in the article. This would be all the more sensible and interesting if later in the discussion of wood processing methods we would refer to the products of the company Ledinek or e.g. the project assignments themselves on the production process of making such glues with machines and production lines of the Ledinek Company, and thus get a continuous learning process.

If I mentioned earlier examples of learning about semi-finished wood products in connection with the contents of the company Ledinek, below I show (Table 2) the methods of wood processing that students encounter in practical lessons in connection with the methods of wood processing offered by Ledinek through its products. Such connections give the student a broader insight into this type of area.

A good example of the concrete introduction of content from the company into the education process will be presented below.

Glued wood, which we got to know through the theoretical part (Figure 11) and its method of production and processing (Table 2), can also be seen within our project, in the form of an excursion. We can see the entire production line of the company Ledinek, how machines can be made for such and other glued wood and how the glued wood itself, with this type of technology, can gain in quality and better usability. We can also transfer this knowledge to the school workshop, to our project. As an example of project work, I can point out the project task, which is related to the production of a birdhouse from glued wood.

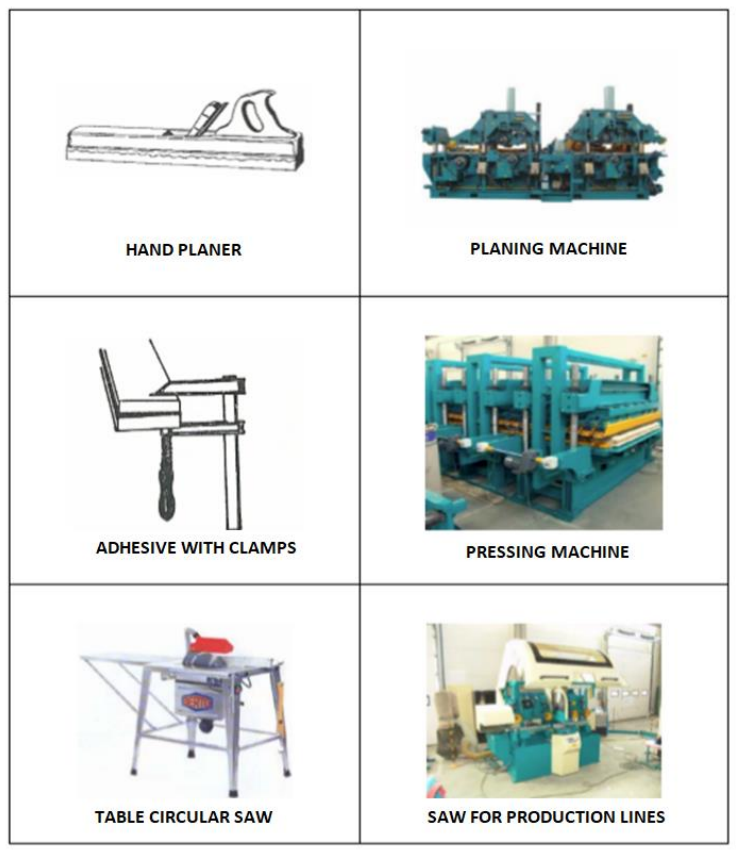

Table 2: Some connections between school and industrial woodworking methods

Through the project, students develop their own ideas, make a prototype, with possible corrections and then prepare the appropriate technical documentation for the product. All this, of course, can be transferred to serial production and make several such houses. This can be a good idea for e.g. school bazaar.

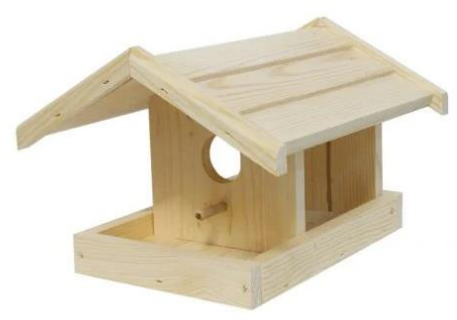

Figure 12: Example of the idea of making a birdhouse through a project

\section{Conclusion}

In the article, I tried to find a connection within the contents of production systems in connection with primary education. It is true that the field of production systems is very wide, but if we focus directly on production in conjunction with other systems (design, prototyping, production preparation, assembly, product control, product, etc.) we find that these contents are very common relate to learning content in primary education and 
could certainly be even more so. This gives the student a better understanding and awareness of work processes and economic and sociological factors in society. The concrete contents that I connected throughout the whole issue seem interesting and topical to me. In this way, by converging such content, the subject of Technic and Technology and its elective subjects can become interesting, more attractive and at the same time a good motivation for later career guidance of students themselves. Definitely, the practical work, through the project method of guiding students on the aforementioned case of making a birdhouse and the content of the project to the project work of Ledinek, is another good example of the transfer of content from the real world to primary education.

\section{Literature}

Aberšek, B. (2007). Proizvodni sistemi. Zbrano gradivo. Maribor: Visoka šola za tehnologije in sisteme Novo Mesto.

Aberšek, B. (2012) Didaktika tehniškega izobraževanja med teorijo in prakso, Ljubljana, ZRSŠ Fošnarič, S., Pucer, Z., Slukan, D., Virtič, J. (2004).

Gerlič, I.. (1983). Tehnologija in obdelava nekovinskih materialov. Maribor: Pedagoška akademija Maribor.

Grošelj, A. (1994). Tehnologija delovnih procesov 1. Ljubljana: Lesarska založba.

Grošelj, A. (1995). Tehnologija delovnih procesov 2. Ljubljana: Lesarska založba.

Papotnik, A. (1984). Od ideje do proizvodnje. Ljubljana: DDU Univerzum.

Papotnik, A. (1998). S projektno nalogo do boljšega znanja. Trzin: Izolit.

Papotnik, A., Čeplak T. (2007). Izbrane teme in vsebine iz didaktike tehnične vzgoje II. Zbrano gradivo. Maribor: Univerza v Mariboru, Fakulteta za naravoslovje in matematiko.

Papotnik, A., Florjančič, F., Angleitner, G., Glodež, S., Hajdinjak, L., Karner, B., i dr. (2002). Učni načrt Tehnika in tehnologija. Ljubljana: Ministrstvo za šolstvo in šport.

Polajnar, A. (1992). Študija dela. Fakulteta za strojništvo, Maribor.

Puncer Z. (2005). Obdelava gradiv-les. Delovni zvezek za izbirni predmet $v$ devetletni osnovni šoli. Limbuš: Izotech založba.
Puncer Z. (2005). Obdelava gradiv-les. Učbenik za izbirni predmet $v$ devetletni osnovni šoli.Limbuš: Izotech založba.

Rihtar, A. (2002). Kvalitetna priprava kratkih elementov za dolžinsko spajanje in širinsko lepljenje lesa. Les, 54(1/2), 11-14.

Rihtar, A. (2009). Vrhunska obdelava lesenih površin z rotoles sistemi. Lesarski utrip, 7(9), 20-22. gradivo. Maribor: Univerza v Mariboru, Fakulteta za naravoslovje in matematiko.

Sušnik, B., Justin, N. in Podbelšek, M. (2005). Učni načrt za izbirni predmet. Obdelava gradiv. Ljubljana: Ministrstvo za šolstvo in šport.

Tehnika in tehnologija 6. Učbenik za 6. razred devetletne osnovne šole. Limbuš: Izotechzaložba. Fošnarič, S., Pucer, Z., Slukan, D., Virtič, J. (2004).

Tehnika in tehnologija 6. Delovni zvezek za 6. razred devetletne osnovne šole. Limbuš: Izotech založba.

Vitrih, I., (2012). Proizvodni sistemi v osnovnošolskem izobraževanju. Diplomsko delo, Maribor: Univerza v Mariboru, Pedagoška fakulteta. 